\title{
AKTSAR
}

ISSN 2622-5255 (online)

\section{Peranan Sistem Informasi Akuntansi dan Tantangan Profesi Akuntan di Era Revolusi Industri 4.0 (Sebuah Studi Fenomenologi)}

\author{
Iwan Fahri Cahyadi \\ Institut Agama Islam Negeri Kudus \\ iwanfahri@iainkudus.ac.id
}

\begin{abstract}
\end{abstract}
In the last few years appeared a variety of breakthrough technology that generates new values in human life through a form of artificial intelligence, big data, internet of things (IoT). Business circles call the third it as the core of the industrial revolution 4.0. These conditions have an impact on the role of the human being, particularly the challenges of the profession of accountants who will be replaced by the role of the robot. The purpose of this research is to provide a solution so that the role of the accountants still exist in the era of the industrial revolution 4.0. As for qualitative research methods via the fenomenalogi approach i.e. we allow qualitative researchers implement and apply subjective abilities and exploratory process in interpersonalnya. Results of the study so that the accountant still exist in the era of the industrial revolution 4.0 then the accountant to start learning programming and algorithms to be able to adapt to change, if you don't use the technology, then the role of the accountant will be replaced by robots.

Keywords: Accounting Information Systems; Accountant; Industrial Revolution 4.0; Fenomenology 


\begin{abstract}
ABSTRAK
Dalam beberapa tahun terakhir muncul berbagai terobosan teknologi yang menghasilkan nilai baru dalam kehidupan manusia melalui bentuk kecerdasan buatan, data yang besar, internet of things (IoT). Kalangan bisnis menyebut ketiga hal tersebut sebagai inti dari revolusi industri 4.0. Kondisi ini berdampak pada peran manusia, khususnya profesi akuntan yang akan digantikan oleh peran robot. Tujuan penelitian ini adalah memberikan solusi agar peran akuntan tetap eksis di era revolusi industri 4.0. Adapun metode penelitian kualitatif melalui pendekatan fenomenalogi yaitu metodelogi kualitatif yang mengizinkan peneliti menerapkan dan mengaplikasikan kemampuan subyektif dan interpersonalnya dalam proses eksploratori. Hasil penelitian ini adalah profesi akuntan bisa tetap eksis di era revolusi industri 4.0 dengan mulai mempelajari pemrograman komputer dan algoritma agar dapat beradaptasi terhadap perubahan, jika tidak menggunakan teknologi, maka peran akuntan akan tergantikan oleh robot.
\end{abstract}

Kata kunci: Sistem Informasi Akuntansi; Profesi Akuntan; Revolusi Industri 4.0, Fenomenologi

\title{
PENDAHULUAN
}

Dunia saat ini dimana telah memasuki era disrupsi dengan ditandai era revolusi industri 4.0. Hal yang perlu dilakukan adalah bagaimana kita harus mampu menyesuaikan dan menyelaraskan perubahan kondisi lingkungan yang ada. Bagi perusahaan, mau tidak mau, siap atau tidak, harus mampu beradaptasi secara cepat jika menginginkan usahanya tetap bertahan dan tidak tersingkir dari kancah persaingan yang semakin kompetitif.

Disrupsi ditandai dengan perubahan secara fundamental dan mendasar. Satu diantara yang membuat terjadi perubahan mendasar adalah revolusi teknologi yang menyasar pada celah kehidupan manusia. Digitalisasi adalah akibat dari revolusi teknologi, terutama informasi yang mengubah hampir semua tatanan kehidupan, termasuk tatanan dalam dunia usaha. Era disrupsi itu di satu sisi memang menciptakan banyak peluang, namun di sisi lain hanya akan memberikan kesempatan sedikit perusahaan untuk menjadi pemenang.

Revolusi industri 4.0 ditandai dengan kemajuan teknologi secara signifikan, salah satunya munculnya teknologi kecerdasan buatan (Artificial Intelegent) yang banyak mengubah banyak hal di bidang kehidupan, di antaranya juga dengan menghilangkan banyak aktivitas yang dahulu dikerjakan manusia. Hal serupa juga merambah banyak aktivitas yang dulunya membutuhkan sentuhan manusia, kini semua direduksi dengan dipakainya kecerdasan buatan untuk banyak kepentingan. Kecerdasan buatan tidak hanya memperkecil kesalahan aktivitas yang dulunya 
ditangani manusia, tetapi bagi perusahaan merupakan capaian efektifitas dan efisiensi dalam operasionalnya.

Era industri 4.0 memungkinkan penciptaan teknologi tinggi. Teknologi itu bertumbuh 10 kali lipat di dalam kurun waktu lima tahun terakhir ini. Diperkirakan, hingga tahun 2020, sebanyak 5,1 juta pekerjaan akan hilang karena dilanda laju era disrupsi (Schwab dan Samans, 2016).

Dalam lingkungan kerja yang semakin cepat, tugas dan pekerjaan rutin telah diambil alih mesin otomatis. Sumber Daya Manusia (SDM) dengan ketrampilan yang ahli dan kreatif, sekarang diperlukan lebih dari sebelumnya untuk memastikan keberlanjutan daya saing tenaga kerja secara nasional.

Menurut Human Capital Index 2017, Indonesia berada di urutan paling bawah, yakni urutan 65 dibandingkan dengan Malaysia pada posisi 33, Filipina ke50 dan Vietnam pada urutan 64. Melihat fakta-fakta tersebut, ditambah lagi dengan kondisi ketenagakerjaan di Indonesia saat ini, maka sumber daya manusia di segala profesi perlu melakukan peningkatan kompetensi, termasuk aktivitas profesi akuntan dalam sistem kerjanya, khususnya Sistem Informasi Akuntansi (SIA) yang berkaitan dengan teknologi informasi, seperti Financial Technology, Big Data, perkembangan ilmu akuntansi dalam bidang-bidang khusus, serta bervariasinya sistem akuntansi keuangan seperti perkembangan lembaga perbankan maupun keuangan syariah dan lain sebagainya.

Berdasarkan masalah di atas maka tujuan dari penelitian ini adalah memberikan solusi kepada peran profesi akuntan dalam menghadapi tantangan di era revolusi industri 4.0 sehingga profesi akuntan tetap eksis.

\section{TINJAUAN LITERATUR}

Pada era informasi teknologi informasi saat ini, perusahaan tidak bisa terlepas dari kebutuhan Sistem Informasi Manajemen (SIM). Oleh karena itu, sistem informasi merupakan kebutuhan vital bagi perusahaan. Menurut Abdurrahman (2013), bahwa sistem informasi sangat penting bagi perusahaan, diantaranya:

1. Sistem informasi merupakan suatu sistem untuk mengubah data menjadi informasi yang berguna bagi manajer dalam pengambilan keputusan. Fakta dan data adalah bahan mentahnya, sedangkan informasi adalah interpretasi data yang berarti dan berguna.

2. Sistem informasi berguna untuk meningkatkan kinerja.

3. Sistem informasi membantu dalam penjadwalan pekerjaan sehari-hari, mengevaluasi prospektif karyawan, dan merumuskan strategi bisnis perusahaan.

4. Sistem informasi juga berguna untuk menganalisis masalah manajemen, terutama untuk tujuan-tujuan kontrol, menerapkan standar kendali kualitas untuk produksi, membandingkan harga dengan anggaran, menyimpan catatan mengenai ketidakhadiran dan tingkat perputaran karyawan.

5. Sistem informasi juga penting dalam perencanaan, khususnya perencanaan untuk memutuskan produk dan pasar perusahaan dalam 10 tahun mendatang.

6. Sistem informasi berguna untuk merumuskan strategi, mislanya strategi untuk penyediaan barang, penerimaan pesanan pelanggan dan memenuhi pesanan dengan segera. 
Informasi sebagai hasil dari pemrosesan atau pengelolaan harus memenuhi syaratsyarat berikut:

1. Relevan, artinya informasi yang diperoleh tersebut sebaiknya sesuai atau signifikan dengan kebutuhan organisasi atau perusahaan.

2. Akurat, artinya informasi yang diperoleh sebaiknya mampu memecahkan masalah yang dibutuhkan organisasi.

3. Up to date, artinya informasi tersebut bukan informasi yang sudah using/tertinggal zaman, melainkan benar-benar informasi yang terbaru.

4. Mengalir secara periodik, artinya informasi tersebut secara terus-menerus dipantau dan mampu membantu manajer dalam setiap keputusan.

Pada hakikatnya, aktivitas atau operasional perusahaan tidak terlepas dari keuangan dan ini membutuhkan pencatatan (akuntansi). Divisi pemasaran berhubungan dengan biaya promosi, survei konsumen, distribusi produk dan lainlainnya. Divisi produksi berhubungan dengan pembelian bahan baku, pemeliharaan mesin, dan sebagainya. Divisi sumber daya manusia berhubungan dengan pengupahan, tunjangan-tunjangan, dan lain-lain. Divisi informasi teknologi berhubungan dengan pembelian dan pemeliharaan hardware, software, dan sebagainya.

Begitu kompleksnya operasional perusahaan, sehingga Sistem Informasi Manajemen mutlak dimiliki oleh perusahaan untuk menjalankan dan mendukung bisnisnya. Salam satu sub Sistem Informasi Manajemen adalah Sistem Informasi Akuntansi (SIA) sangat penting dalam mendukung aktivitas tersebut dan mencatat transaksi keuangan yang terjadi sehingga mampu menyediakan laporan keuangan sebagai alat pengambilan keputusan manajemen maupun memenuhi kebutuhan pihak luar, seperti investor, pemerintah, dan lain-lain.

Menurut Sunyoto (2014), Sistem Informasi Akuntansi melaksanakan aplikasi akuntansi perusahaan yang ditandai dengan volume pengolahan data yang tinggi dimana pengolahan itu sendiri meliputi pengumpulan data, manipulasi data, penyimpanan data, dan penyiapan dokumen. Suatu perusahaan tidak dapat menentukan untuk memiliki Sistem Informasi Akuntansi atau tidak, itu merupakan suatu keharusan. Sistem informasi akuntansi lebih berorientasi pada data daripada berorientasi informasi, dan datanya sebagian besar bersifat historis.

Sistem informasi akuntansi juga mengalami perkembangan-perkembangan, mulai dari konsep double entry book keeping system, hingga sebagai sistem berbasis komputer, bahkan kini menjadi bagian integral dari keseluruhan sistem terpadu yang disebut enterprise information system. Faktor-faktor yang mendorong perkembangan sistem informasi akuntansi sampai dalam bentuknya sekarang ini antara lain adalah sebagai berikut:

1. Perkembangan sistem pengolahan data dan peralatannya yang memungkinkan sistem informasi akuntansi tidak hanya mampu menyajikan laporan akuntansi keuangan melainkan juga berbagai informasi akuntansi manajemen dan bahkan laporan-laporan non- keuangan yang sangat penting bagi dukungan pengendalian organisasi.

2. Meningkatnya kompleksitas operasional perusahaan menyebabkan sistem informasi (khususnya informasi akuntansi) menjadi makin penting sebagai alat bantu manajemen. 
3. Meningkatnya kompleksitas organisasi, multinasional, konglomerasi dan organisasi maya (virtual organization), menyebabkan perlunya perhatian dan kesungguhan untuk membangun, mengelola, dan memberdayakan sistem informasi akuntansi menjadi makin meningkat.

4. "Tempo" kegiatan, speed, dan tingkat toleransi pelayanan makin rendah, artinya suatu keslahan pengambilan keputusan dapat langsung mempunyai dampak yang relatif cukup besar. Karena itu peranan sistem informasi akuntansi dalam menyediakan bahan untuk proses pengambilan keputusan makin penting.

5. Terjadi globalisasi kegiatan dan makin perlunya sistem informasi akuntansi menjadi media komunikasi bisnis antarlokasi dan antarnegara.

6. Sistem informasi akuntansi makin diperlukan untuk memberikan masukan maupun sebagai alat pemicu (trigger) bagi pengembangan sistem informasi manajemen fungsional lainnya.

Perkembangan sistem informasi akuntansi terus mengalami perubahan yang signifikan. Kondisi ini menjadi tantangan profesi akuntan sekaligus menuntut untuk mampu beradaptasi dan meningkatkan kompetensi kalau tidak ingin tersingkir dari persaingan.

Hal senada juga direkomendasikan oleh Iswanto \& Wahjono, 2019 dalam jurnalnya yang berjudul "Pengaruh Revolusi Industri 4.0 Terhadap Ilmu Akuntansi ESAI" yang merekomendasikan bahwa Diperlukan studi dan riset lanjutan untuk merumuskan mengenai metode dan ragam pembelajaran profesi akuntan dan mahasiswa akuntansi sehingga stigma akuntan sebagai "book keeper" menjadi lebih luas dan memiliki nilai tambah yang konstruktif disesuaikan dengan karakterisitik dan fokus industri 4.0 dimana peran dan fungsinya menjadi lebih variatif.

Namun dalam jurnal tersebut, penulis tidak merekomendasikan secara spesifik hal yang perlu dilakukan bagi peran profesi akuntan dalam menghadapi tantangan di era revolusi Industri 4.0. Untuk itu dalam tulisan jurnal ini akan merekomendasikan secara spesifik berdasarkan masalah dan peluang yang ada agar profesi akuntan tetap eksis dalam menghadapi tantangan revolusi industri 4.0.

\section{METODE}

Metode penelitian menggunakan kualitatif yaitu metode penelitian yang berlandaskan pada filsafat postpositivisme yaitu memandang realitas sosial sebagai suatu yang holistik atau utuh, kompleks, dinamis, penuh makna, dan hubungan gejala bersifat interaktif (Narbuko, et.al, 2002). Metode kualitatif bersifat diskriptif, yakni data yang terkumpul berbentuk kata atau gambar, tidak hanya menekankan pada angka (Sugiono, 2008). Adapun pendekatan yang digunakan adalah fenomenalogi yaitu metodelogi kualitatif yang mengizinkan peneliti menerapkan dan mengaplikasikan kemampuan subyektif dan interpersonalnya dalam proses eksploratori (Alase, 2017). Adapun sumber data diperoleh dari data sekunder yaitu sumber data yang tidak langsung memberikan data kepada pengumpul data, misalkan dokumen, jurnal, hasil penelitian, buku, dan peraturan pemerintah (Basrowi, 2008). 


\section{HASIL DAN PEMBAHASAN}

\section{Sejarah dan Perkembangan Revolusi Industri}

Sejarah membuktikan, bahwa perubahan di dunia usaha begitu cepat, yang disebut dengan revolusi industri. Revolusi Industri merupakan periode antara tahun 1750-1850 di mana terjadinya perubahan secara besar-besaran di bidang pertanian, manufaktur, pertambangan, transportasi, dan teknologi serta memiliki dampak yang mendalam terhadap kondisi sosial, ekonomi, dan budaya di dunia. Revolusi Industri dimulai dari Britania Raya dan kemudian menyebar ke seluruh Eropa Barat, Amerika Utara, Jepang, dan menyebar ke seluruh dunia.

Revolusi Industri menandai terjadinya titik balik besar dalam sejarah dunia, hampir setiap aspek kehidupan sehari-hari dipengaruhi oleh Revolusi Industri, khususnya dalam hal peningkatan pertumbuhan penduduk dan pendapatan rata-rata yang berkelanjutan dan belum pernah terjadi sebelumnya. Selama dua abad setelah Revolusi Industri, rata-rata pendapatan perkapita negara-negara di dunia meningkat lebih dari enam kali lipat.

Inggris memberikan landasan hukum dan budaya yang memungkinkan para pengusaha untuk merintis terjadinya Revolusi Industri. Faktor kunci yang turut mendukung terjadinya Revolusi Industri antara lain: (1) Masa perdamaian dan stabilitas yang diikuti dengan penyatuan Inggris dan Skotlandia, (2) tidak ada hambatan dalam perdagangan antara Inggris dan Skotlandia, (3) aturan hukum (menghormati kesucian kontrak), (4) sistem hukum yang sederhana yang memungkinkan pembentukan saham gabungan perusahaan (korporasi), dan (4) adanya pasar bebas (kapitalisme).

Revolusi Industri dimulai pada akhir abad ke-18, di mana terjadinya peralihan dalam penggunaan tenaga kerja di Inggris yang sebelumnya menggunakan tenaga hewan dan manusia, yang kemudian digantikan oleh penggunaan mesin yang berbasis menufaktur. Periode awal dimulai dengan dilakukannya mekanisasi terhadap industri tekstil, pengembangan teknik pembuatan besi dan peningkatan penggunaan batubara. Ekspansi perdagangan turut dikembangkan dengan dibangunnya terusan, perbaikan jalan raya dan rel kereta api. Adanya peralihan dari perekonomian yang berbasis pertanian ke perekonomian yang berbasis manufaktur menyebabkan terjadinya perpindahan penduduk besar-besaran dari desa ke kota, dan pada akhirnya menyebabkan membengkaknya populasi di kota-kota besar di Inggris.

Awal mula Revolusi Industri tidak jelas tetapi T.S. Ashton menulisnya kirakira 1760-1830. Tidak ada titik pemisah dengan Revolusi Industri II pada sekitar tahun 1850, ketika kemajuan teknologi dan ekonomi mendapatkan momentum dengan perkembangan kapal tenaga-uap, rel, dan kemudian di akhir abad tersebut perkembangan mesin pembakaran dalam dan perkembangan pembangkit tenaga listrik.

Faktor yang melatarbelakangi terjadinya Revolusi Industri adalah terjadinya revolusi ilmu pengetahuan pada abad ke 16 dengan munculnya para ilmuwan seperti Francis Bacon, René Descartes, Galileo Galilei serta adanya pengembangan riset dan penelitian dengan pendirian lembaga riset seperti The Royal Improving Knowledge, The Royal Society of England, dan The French Academy of Science. Adapula faktor dari dalam seperti ketahanan politik dalam negeri, perkembangan kegiatan wiraswasta, jajahan Inggris yang luas dan kaya akan sumber daya alam. 
Istilah "Revolusi Industri" sendiri diperkenalkan oleh Friedrich Engels dan Louis-Auguste Blanqui di pertengahan abad ke-19. Beberapa sejarawan abad ke-20 seperti John Claphamdan Nicholas Crafts berpendapat bahwa proses perubahan ekonomi dan sosial yang terjadi secara bertahap dan revolusi jangka panjang adalah sebuah ironi. Produk domestik bruto (PDB) per kapita negara-negara di dunia meningkat setelah Revolusi Industri dan memunculkan sistem ekonomi kapitalis modern. Revolusi Industri menandai dimulainya era pertumbuhan pendapatan per kapita dan pertumbuhan ekonomi kapitalis. Periode ini Revolusi Industri 1.0.

Tuntutan menjadi produktif terus berlanjut hingga memasuki awal abad ke-20. Revolusi Industri 2.0 dimulai. Pedekatan scientific management Frederick W Taylor diaplikasikan pada pabrik mobil Ford untuk memproduksi secara massal. Produksi secara massal yang bekerja di suatu assembly line itulah yang merombak cara bekerja untuk menghasilkan barang agar lebih cepat dan murah.

Awal Revolusi Industri 3.0 ditandai dengan tuntutan produksi dengan produktivitas tinggi tidak terhenti. Penemuan Programmable Logic Controller (PLC) pada tahun 1960-an memungkinkan otomatisasi dan robotisasi dalam sistem produksi. Kondisi ini mendorong produksi massal dilakukan secara lebih berkualitas, lebih cepat, dan lebih murah. Sejalan dengan waktu, tuntutan pembuat barang tidak hanya sebatas bekerja otomatis dalam internal pabrik. Lebih dari itu, produsen harus mampu mengorkestrasikan siapapun mitranya dalam jejaring pasokan untuk memenuhi segala permintaan pasar secara responsif sekaligus efisien.

Produksi masal pada industri 2.0 ditambah otomatisasi di industri 3.0 tepat untuk proses produksi dengan volume tinggi dan varian produk rendah. Semakin canggih pengguna, perusahaan harus bisa membuat berbagai produk yang diinginkan dalam jumlah berapapun. Itulah tantangan utama yang belum terjawab hingga industri 3.0. Lantas datanglah industri 4.0 untuk menjawab.

Industri 4.0 terkait dengan optimalisasi semua sumber daya yang ada dalam jejaring bisnis untuk memenuhi semua permintaan pasar. Optimalisasi sebenarnya bukan hal yang baru, tetapi pembedanya adalah "bagaimana memainkan" dalam upaya tersebut. Bagaimana memainkan ditentukan oleh orkestrasi solid berbagai teknologi pendukung, di antaranya internet of things, 3D printing, cloud computing, artificial intelligence, dan big data analytics di samping teknologi robot yang kian otonom (Cahyadi, 2018).

\section{Sistem Informasi Akuntansi di Era Revolusi Industri 4.0}

\section{Artificial Intellegence}

Sejarah mencatat bahwa semula penggunaan komputer di dunia usaha terbatas pada pemrosesan transaksi. Pada tahun 1960-an, konsep Sistem Informasi Manajemen muncul setelah ditemukannya kebutuhan untuk menyediakan informasi kepada para manajer. Kebutuhan Sistem Informasi Manajemen amatlah luas, dan berusaha untuk memberikan informasi kepada semua manajer di perusahaan untuk digunakan dalam penyelesaian semua permasalahan. Ini merupakan upaya yang amat ambisius dan banyak sistem gagal untuk memenuhi ekspektasi. Hal ini disebabkan karena permasalahan di perusahaan tidak semata-mata menangani masalah yang terstruktur, tetapi juga masalah yang semi dan tidak terstruktur. 
Kondisi ini membawa konsekuensi bahwa permasalahan yang ada tetapi menggunakan manajer dan komputer. Posisi komputer disini sebagai sistem pendukung pengambilan keputusan (Decision Support System/DSS), artinya DSS tidak pernah ditujukan untuk menyelesaikan masalah tanpa bantuan manajer. Jadi DSS menekankan penggunaan permodelan matematika dan pengajuan permintaan ke basis data.

Dengan kondisi kurang maksimalnya DSS, maka para perancang DSS mulai menyadari kebutuhan untuk menggabungkannya dengan kecerdasan buatan (Artificial Intellegence/AI). Kecerdasan buatan adalah aktivitas penyediaan mesin seperti computer dengan kemampuan untuk menampilkan perilaku yang dianggap sama cerdasnya dengan jika kemampuan tersebut ditampilkan oleh manusia. Kecerdasan buatan merupakan aplikasi computer yang paling canggih karena palikasi ini berusaha mencontoh cara pemikiran manusia.

AI diterapkan di dunia bisnis dalam bentuk sistem pakar, jaringan saraf tiruan, algoritma genentik dan agen cerdas. Secara ringkas penjelasannya sebagai berikut:

a. Sistem pakar (expert system), adalah program komputer yang berusaha mewakili pengetahuan keahlian manusia dalam bentuk heuristic. Istilah heuruistik diambil dari bahasa Yunani yang berarti menemukan, jadi heuristic adalah aturan yang menjadi patokan atau aturan untuk menebak dengan baik. Heuristik tidak menjamin sebaik algoritma yang biasa didapatkan dalam model matematika, namun heuruistik biasanya menawarkan hasil yang cukup spesifik sehingga dapat berguna. Heuristik memungkinkan sistem pakar untuk berfungsi sedemikian rupa agar konsisten dengan keahlian manusia, dan menyarankan penggunaannya cara memecahkan masalah. Karena sistem pakar berfungsi sebagai konsultan, tindakan menggunakan aplikasi ini disebut konsultasi. Karena berkonsultasi kepada sistem pakar untuk mendapatkan saran. Sistem pakar dirancang oleh spesialis informasi (yang seringkali di sebut insiyur pengetahuan/knowledge engineer) yang memiliki keahlian khusus dalam bidang kecerdasan buatan. Insiyur pengetahuan amat ahli dalam mendapatkan ilmu dari seorang ahli. Sistem pakar menawarkan kemampuan yang unik sebagai sistem pendukung keputusan. Pertama, sistem pakar memberikan kesempatan untuk membuat keputusan melebihi kemampuan seorang manajer. Sebagai contoh, seorang karyawan investasi baru di bank dapat menggunakan suatu sistem pakar yang didesain oleh seorang ahli keuangan dan dengan demikian menggabungkan pengetahuan ahli tersebut ke dalam keputusan investasinya. Kedua, sistem pakar tersebut dapat menjelaskan alasannya hingga menuju ke suatu keputusan. Seringkali, penjelasan mengenai bagaimana solusi tersebut dicapai lebih berharga dibandingkan solusi itu sendiri.

b. Jaringan Saraf Tiruan (neural networks) meniru fisiologi otak manusia. Jaringan ini mampu menemukan dan membedakan pola, sehingga membuatnya amat berguna dalam bisnis di wilayah pengenalan suara dan pengenalan karakter optis.

c. Algoritma Genetik (Genetic algorithms) menerapkan proses “yang terkuat yang selamat" untuk memungkinkan para pemecah masalah agar menghasilkan solusi masalah yang semakin lebih baik. Contohnya, banker investasi dapat 
menggunakannya untuk memilih portfolio investasi yang terbaik bagi kliennya.

d. Agen Cerdas (intelligent agent) digunakan untuk melakukan tugas yang berkaitan dengan computer yang berulang-ulang. Salah satu contohnya adalah penggabungan data, dimana penemuan pengetahuan memungkinkan sistem gudang data untuk mengidentifikasi hubungan data yang sebelumnya tidak dikenal.

Perkembangan AI saat ini sudah jauh lebih maju karena didukung oleh perkembangan teknologi yang semakin pesat, sehingga dikemudian hari akan mengambil alih atau menggantikan beberapa profesi pekerjaan yang ada saat ini, termasuk profesi akuntan (McLeod, Jr. dan Schell, 2009).

\section{Big Data}

Menurut Widy (2017), Era digital telah mendorong dunia ke arah revolusi industri 4.0 yang dicirikan oleh perpaduan teknologi yang mengaburkan batas antara fisik, digital, dan biologis. Hal ini ditandai dengan hadirnya sejumlah terobosan teknologi baru di sejumlah bidang, di antaranya adalah robotika, kecerdasan buatan, blockchain, Internet of Things (IoT), dan lainnya.

Pengolahan dan pemanfaatan data yang masif atau yang biasa dikenal dengan teknologi big data telah menjadi faktor penting yang melandasi terobosan tersebut. Kini data bukan lagi faktor pelengkap, namun telah menjadi senjata utama untuk memenangi persaingan di berbagai bidang. Big data adalah data yang memiliki volume besar sehingga tidak dapat diproses menggunakan alat tradisional biasa dan harus menggunakan cara dan alat baru untuk mendapatkan nilai dari data ini.

Setiap hari kita menciptakan banyak data, data ini bisa berasal dari mana saja; posting ke situs media sosial, gambar digital dan video, catatan transaksi pembelian dan lain-lain. Data ini adalah big data. Artinya jika volume data membuat data tersebut tidak ekonomis atau mungkin lagi untuk disimpan di solusi penyimpanan data tradisional (network storage atau database atau data warehouse), maka itu bisa disebut big data.

Teknologi big data muncul untuk memecahkan suatu masalah atau mempermudah penyelesaian suatu masalah. Masalah yang dapat dipecahkan dengan big data, paling tidak terdapat 3 masalah utama yang big data coba selesaikan. Masalah tersebut biasa disebut dengan 3V (Volume, Velocity, Variety)

a. Volume, yaitu salah satu permasalahan big data yang dicoba untuk dipecahkan adalah meledaknya volume data yang suatu organisasi ingin simpan atau proses. Seberapa besar data yang bisa diolah saat ini? Apakah dengan jumlah data yang dimiliki sudah lebih baik dibanding kompetitor? Data yang ada saat ini berukuran sangat besar. Di tahun 2000, tercatat 800,000 petabyte data tersimpan di seluruh dunia dan angka ini diperkirakan akan mencapai 35 zettabyte di tahun 2020 atau bahkan lebih.

Sebenarnya suatu sistem database atau data warehouse pun bisa menyimpan data yang sangat besar. Namun, cost platform big data jauh lebih rendah dibandingkan keduanya. Selain itu, berbeda dengan sekedar network storage, teknologi big data tidak hanya menyediakan solusi untuk menyimpan data, namun juga untuk mengolah dan menganalisa data bervolume besar. 
Bayangkan jika anda membutuhkan analisis terhadap 1 persen saja dari seluruh data untuk mendapatkan keuntungan dibandingkan kompetitor anda, maka teknologi yang anda miliki sekarang mampu melakukannya atau tidak. Bila tidak mampu maka perusahaan anda akan kalah cepat dalam mengambil keputusan sehingga akan kalah bersaing.

b. Velocity, yaitu permasalahan yang berkaitan erat dengan permasalahan volume data, karena kecepatan data dibuat umumnya berbanding lurus dengan volume data. Data tidak hanya datang dalam jumlah besar, tetapi juga dalam tempo yang lebih singkat dan bahkan ada yang real-time.

c. Variety, yaitu permasalahan yang terjadi karena keberagaman data, baik itu dari format file data yang masuk, maupun format / struktur dari isi data tersebut. Permasalahan ini akan sangat sulit dipecahkan oleh data platform tradisional, baik itu database atau data warehouse. Big Data tidak hanya terdiri dari data berstruktur seperti halnya data angka-angka maupun deretan hurufhuruf yang berasal dari sistem database mendasar seperti halnya sistem database keuangan, tetapi juga terdiri atas data multimedia seperti data teks, data suara dan video yang dikenal dengan istilah data tak berstruktur. Terlebih lagi, Big Data juga mencakup data setengah berstruktur seperti halnya data email maupun Extensible Markup Language (XML).

Big Data tidak hanya berputar pada jumlah data yang organisasi miliki, tetapi hal yang penting adalah bagaimana mengolah data internal dan eksternal. Kita dapat mengambil data dari sumber manapun dan menganalisanya untuk menemukan jawaban yang diinginkan dalam bisnis seperti: pengurangan biaya, pengurangan waktu, pengembangan produk baru dan optimalisasi penawaran produk; dan pengambilan keputusan yang cerdas. Ketika organisasi mampu menggabungkan jumlah data besar yang dimilikinya dengan analisis bertenaga tinggi, organisasi dapat menyelesaikan tugas-tugas yang berhubungan dengan bisnis seperti: menentukan akar penyebab kegagalan untuk setiap masalah bisnis, menghasilkan informasi mengenai titik penting penjualan berdasarkan kebiasaan pelanggan dalam membeli, menghitung kembali seluruh risiko yang ada dalam waktu yang singkat.

\section{Financial Technology}

Perusahaan rintisan atau dikenal dengan start-up khusus penyedia jasa fiansial atau financial technology (Fintech) bermunculan di Indonesia. Fintech menawarkan inovasi dalam jasa keuangan. Tujuannya tidak lain memudahkan masyarakat mengakses produk keuangan, mempermudah transaksi, dan meningkatkan literasi keuangan. Karena itu pula, fintech kerap diartikan sebagai pesaing dunia perbankan. Karena tanpa menjadi nasabah bank, orang bisa melakukan berbagai transaksi keuangan sesuai dengan kebutuhan.

Fintech menjadi fenomena ketika teknologi dan keuangan beradu. Hingga Juni 2018, tingkat penyaluran kredit lewat fintech lending telah mencapai Rp. 7,64 triliun. Nilai ini tumbuh berkali lipat dibandingkan nilai penyaluran akhir Desember 2016 yang baru mencapai Rp. 200 miliar. 
Di Indonesia, fintech berkembang di berbagai sektor, dari start-up pembayaran, peminjaman (lending dan peer to peer lending), perencanaan keuangan (personal finance), investasi ritel, pembiayaan (crowdfunding), remitansi, riset keuangan, dan lain-lain. Hingga kini jumlah fintech yang terdaftar di Otoritas Jasa Keuangan (OJK) per Februari 2019 sebanyak 99 perusahaan. Sedangkan total asset sebesar Rp. 2.390.190, 20 miliar yang terdiri dari Rp. 2.289.806, 66 miliar untuk industri keuangan non bank konvesional dan 100.383, 54 miliar untuk industri keuangan syariah (OJK, 2019).

\section{Peranan Sistem Informasi Akuntansi}

Dalam beberapa tahun ini kita diperlihatkan berbagai terobosan teknologi yang menghasilkan nilai-nilai baru dalam kehidupan manusia melalui bentuk kecerdasan buatan (Artificial Intellegent), Big Data, dan Internet of Things (IoT). Kalangan bisnis menyebut ketiganya sebagai inti dari revolusi industri 4.0. Terminologi ini menekankan ada interkoneksi data berbagai pihak yang terkumpul menjadi big data melalui perangkat-perangkat yang terhubung ke internet dan kemudian diolah menggunakan kecerdacan buatan untuk menghasilkan keputusankeputusan penting di dalam industri maupun kehidupan masyarakat. Transformasi tersebut akan banyak mengubah wajah bisnis pada masa depan dan cara hidup manusia. Data bukan hanya menjadi bagian penting bagi manajemen di dunia bisnis, melainkan juga bagi kehidupan masyarakat secara umum.

Bagi perusahaan pada umumnya dan fintech pada khususnya, dituntut mampu merespon dan mengantisipasi perkembangan yang ada. Peran Sistem Informasi Akuntansi menjadi sangat vital mengingat seluruh aktivitas operasional perusahaan berhubungan dengan transaksi keuangan dan itu semua harus tercatat dalam sistem akuntansi perusahaan. Sistem informasi akuntansi yaitu sebuah sistem yang merubah data transaksi bisnis menjadi informasi keuangan yang berguna bagi pemakainya. Adapun tujuan dari sistem informasi akuntansi yaitu untuk mendukung operasioperasi perusahaan sehhar-hari, mendukung keputusan manajemen dan memenuhi kewajiban yang berhubungan dengan pertanggungjawaban.

Secara garis besar sistem informasi akuntansi dapat digambarkan dalam bagan berikut ini.

Gambar 1. Bagan Sistem Informasi Akuntansi

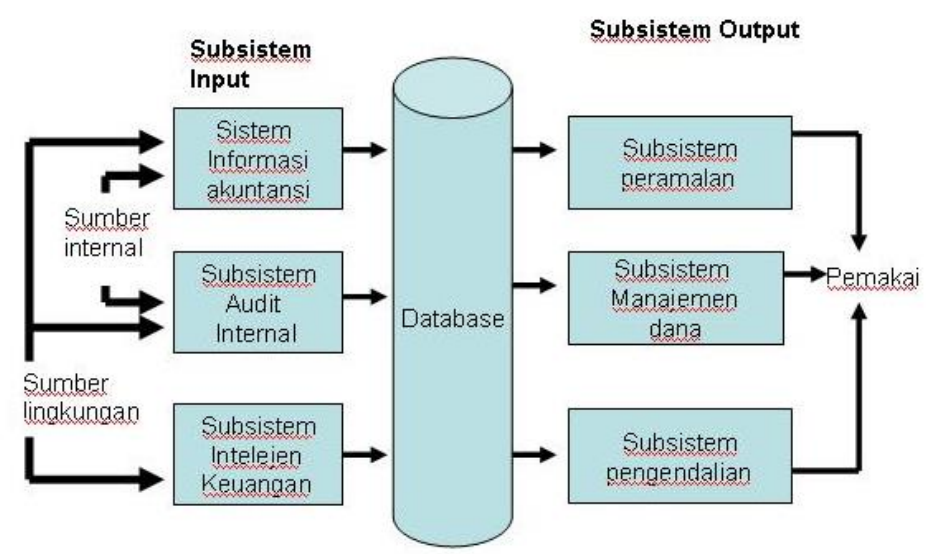

Sumber : Danang Sunyoto (2014) 
Dari bagan di atas dapat dijelaskan secara ringkas peran profesi akun dalam suatu perusahaan, yaitu :

a. Sub Sistem Input : dari sisi internal seluruh aktivitas di dalam perusahaan harus dicatat setiap kali transaksi terjadi melalui sistem informasi akuntansi. Dalam satu hari saja, bagi perusahaan skala menengah besar transaksi bisa mencapai ratusan bahkan ribuan kali. Oleh karena itu, seorang akuntan harus mampu menyediakan apa yang terjadi dengan keuangan perusahaan dengan mengolah data yang ada menjadi suatu informasi. Data-data hasil transaksi di tampung dalam data base perusahaan, sehingga kapanpun pihak internal perusahaan meminta laporan keuangan (neraca, rugi/laba dan cash flow perusahaan) bagian akuntan harus mampu menyediakan informasi tersebut. Transaksi perusahaan yang begitu rumit dan komplek (big data) yang harus tersedia setiap saat tentunya memerlukan kecerdasan buatan (artificial technology) yang dapat menggantikan peran manusia.

Selain itu peran internal audit juga diperlukan mengingat laporan keuangan merupakan salah satu bentuk pertanggungjawaban pemangku kepentingan internal perusahaan maupun informasi tersebut dimanfaatkan oleh pihak eksternal perusahaan seperti pemerintah (pajak), investor, masyarakat dan lain sebagainya. Audit internal selayaknya mampu menjamin pemangku kepentingan bahwa laporan keuangan yang disajikan sudah benar sesuai standar akuntansi dan mendapat penilaian wajar tanpa pengecualian.

Divisi akuntan di perusahaan juga harus jeli melihat kebijakankebijakan dari pihak eksternal (pemerintah, seperti pajak, kondisi makro ekonomi, dan lainnya), laporan keuangan kompetitor, maupun informasiinformasi keuangan lainnya. Semua informasi ini selanjutnya ditampung dalam data base perusahaan sebagai sumber data. Oleh karena itu, profesi akuntan juga berfungsi sebagai intelegen keuangan perusahaan.

b. Data base berisi data-data yang merupakan data-data transaksi internal perusahaan, kebijakan perusahaan, maupun berisi data atau informasi yang berasal dari luar perusahaan. Data mengarah pada fakta-fakta yang kita kumpulkan, simpan dan proses dengan sistem informasi.

c. Sub Sistem Output, merupakan hasil pengolahan data menjadi informasi. Karakteristik informasi yang berguna haruslah relevan, andal, lengkap, tepat waktu, dapat dipahami dan dapat diverifikasi. Biasanya informasi ini dalam bentuk laporan keuangan (neraca, rugi laba dan arus kas perusahaan). Laporan keuangan ini merupakan alat kebijakan perusahaan untuk menyusun rencana kerja anggaran dan pendapatan perusahaan (RKAP) yang identik dengan peramalan (forecasting) tahun anggaran berikutnya.

Laporan keuangan juga dapat memberikan informasi mengenai perlu tidaknya perusahaan menambah dana atau tidak. Hal ini berkenaan dengan rencana ekspansi, tingkat likuiditas, dan lain sebagainya. Selain itu, laporan keuangan, khususnya arus kas dapat digunakan sebagai pedoman dan alat kontrol (pengendalian) tentang pendapatan yang dicapai dan biaya yang dikeluarkan. Jika pendapatan tidak tercapai atau biaya melebihi dari yang direncanakan maka dewan direksi harus segera memecahkan masalah ini. 


\section{Tantangan Profesi Akuntan di Era Revolusi Industri 4.0}

Di era modernisasi seperti sekarang ini, teknologi informasi menjadi tantangan yang cukup berat bagi dunia akuntansi. Sebab, transaksi keuangan mulai tidak lagi hanya menggunakan uang tunai, tetapi juga mata uang digital. Komponen sistem informasi akuntansi meliputi prosedur-prosedur baik manual maupun terotomatisasi yang dilibatkan dalam mengumpulkan, memproses dan menyimpan data tentang aktivitas perusahaan, juga diperlukan software dan infrastruktur teknologi informasi yang dipakai untuk mendukungnya. Adapun komponen lainnya yang penting adalah orang-orang yang mengoperasionalkan sistem tersebut.

Namun saat ini komponen manusia (akuntan) menjadi salah satu profesi yang terkena dampak revolusi industri 4.0. Profesi akuntan adalah salah satu profesi yang mungkin akan tergantikan oleh robot. Hal ini didorong oleh perkembangan big data dan artificial technology. Beberapa tantangan profesi akuntan antara lain:

a. Penggunaan aplikasi mobile bagi perusahaan, sehingga pemilik dan pimpinan perusahaan bisa mengakses data akuntansi atau bisnisnya dari telepon genggam, tablet atau smartphone.

b. Mengelola data korporasi berbasis internet.

c. Pengukuran dan penilaian biaya dan manfaat penggunaan teknologi pada dunia cloud computing dan social networking.

d. Akuntansi akan berkurang karena penggunaan perangkat lunak sehingga akuntansi dijalankan secara mandiri. Dengan demikian audit laporan keuangan akan berbasis real time, regulator dan auditor langsung menarik data secara otomatis dari sistem dan sensor melekat pada kegiatan operasional perusahaan.

Oleh karena itu, para akuntan untuk mulai mempelajari programming dan algoritma agar dapat beradaptasi terhadap perubahan, jika tidak menggunakan teknologi, akuntan akan tergantikan oleh robot.

Demikian juga jika akuntan tidak ahli dalam teknologi informasi, maka profesi lain dapat mengambil alih fungsi akuntan. Akuntan adalah ahli dalam bidang penyedia informasi keuangan maka teknologi informasi menjadi kebutuhan pokok.

\section{SIMPULAN}

Revolusi industri 4.0 ditandai dengan kemajuan teknologi secara signifikan dan penciptaan teknologi tinggi. Revolusi industri ditandai dengan munculnya teknologi kecerdasan buatan (Artificial Intelegent) yang banyak mengubah banyak hal di bidang kehidupan, di antaranya juga dengan menghilangkan banyak aktivitas yang dahulu dikerjakan manusia. Selain itu, munculnya data-data dalam volume besar (big data) yang begitu penting bagi perusahaan untuk diolah menjadi informasi menuntut penyediaan teknologi yang mampu menampung data-data tersebut. Oleh karena itu, Sistem Informasi Akuntansi harus mampu menjawab tantangan di era revolusi industri 4.0. terutama para akuntan harus mampu mempersiapkan diri sehingga mampu memiliki dan meningkatkan kompetensnyai sehingga profesi tersebut tidak diambil alih oleh profesi lainnya. 


\section{DAFTAR PUSTAKA}

Abdurrahman, Nana Herdiana. (2013). Manajemen Bisnis Syari'ah dan Kewirausahaan. Bandung: CV. Pusataka Setia.

Alase, Abayomi. The Interpretative Phenomenological Analysis (IPA): A Guide to a Good Qualitative Research Approach. International Journal of Education and Literacy Studies, Vol. 5 No. 2, April 2017, DOI: 10.7575/aiac.ijels. v.5n.2p.9.

Basrowi, Suwandi. (2008). Memahami Penelitian Kualitatif. Jakarta: Rineka Cipta.

Cahyadi, Iwan Fahri (2018). Sistem Pemasaran Dropship Dalam Perspektif Islam. Tawazun, Volume 1, No.1, Hlm. 4-6.

Iswanto, Alek Candra dan Wahjono. (2019). Pengaruh Revolusi Industri 4.0 Tehadap Ilmu Akuntansi-ESAI. INFOKAM, Nomor I Th. XV/MARET/2019.

McLeod Jr, Raymond \& Schell, George P. (2009). Sistem Informasi Manajemen. Jakarta: Salemba Empat.

Narbuko, Cholid \& Ahmadi, Abu. (2002). Metodologi Penelitian, Jakarta: Bumi Aksara.

OJK. Statistik IKNB bulan Februari 2019. Diakses tanggal 26 Maret 2019. http://www.ojk.go.id/id/kanal/iknb/data-dan-statistik/statistikiknb/Pages/Statistik-IKNB-bulan-Februari-2019.aspx

Schwab, Klaus \& Samans, Richard. (2016). The Future of Jobs: Employment, Skills, and Workforce Strategy for the $4^{\text {th }}$ Industrial Revolution.

Sugiono. (2008). Metode Penelitian Pendidikan: Pendekatan Kuantitatif, Kualitatif dan RED. Bandung: Alfabeta.

Sunyoto, Danang. (2014). Sistem Informasi Manajemen: Perspektif Organisasi. Yogyakarta: Penerbit CAPS.

Walker, Martin. (2007). Addressing the Muslim Market: Can you Afford Not to?. Chicago: AT Kearney.

Widy, Sasongko. (2017). Berkenalan dengan big data. Diakses tanggal 12 Agustus 2017. https:// medium.com/skyshidigital/berkenalan-dengan-big-data$15 f d 941122 f 8$. 